\title{
Advances and controversies in grading and staging of renal cell carcinoma
}

\author{
Brett Delahunt \\ Department of Pathology and Molecular Medicine, Wellington School of Medicine and Health Sciences, \\ University of Otago-Wellington, Wellington, New Zealand
}

\begin{abstract}
Despite the considerable progress made in our understanding of the pathogenesis, genetics, and pathology of renal cell carcinoma (RCC), difficulties remain relating to the prediction of clinical outcome for individual cases. Although there is evidence to show that high-grade tumors have a poorer prognosis when compared to those of low grade, debate remains regarding the predictive value of grading, especially for those tumors classified into the intermediate grades. Numerous composite morphologic and nuclear grading systems have been proposed for RCC and although that of the Fuhrman classification have achieved widespread usage, the validity of the grading criteria of this classification has been questioned. In addition, there are few studies that have attempted to validate the Fuhrman system for RCCs beyond that of the clear cell subtype. Recent studies have indicated that grading of papillary RCC should be based on nucleolar prominence alone and that the components of the Fuhrman grading classification do not provide prognostic information for chromophobe RCC. Independent of tumor grade, the prognostic importance of tumor stage for RCC is well recognized. The Union Internationale Contre le Cancer/American Joint Committee for Cancer Staging and End Results Reporting TNM staging system is now in its sixth edition (2002) and recent refinements have focused on defining size cut points that will identify apparently localized tumors that will develop recurrence and/or metastases despite attempted curative surgery. In parallel with these studies it has been shown that infiltration of the renal sinus is an important prognostic factor, being observed in almost all tumors $>7 \mathrm{~cm}$ in diameter. Questions remain as to the appropriate stratification of regional extension of RCC, as defined in the T3 tumor-staging category. Recent modifications to this category have been suggested combining the level of infiltration of the venous outflow tract with the presence or absence of infiltration of the adrenal gland and/or perirenal fat. Similarly, the utility of classifying lymph node involvement by tumor is debated, although it is well recognized that lymph node infiltration is associated with a poor prognosis. Although the current TNM classification does provide useful prognostic information it would appear that further modifications are justified to enhance the predictive value of staging for RCC.

Modern Pathology (2009) 22, S24-S36; doi:10.1038/modpathol.2008.183
\end{abstract}

Keywords: renal cell carcinoma; grade; stage; sarcomatoid carcinoma; rhabdoid; prognosis

Outcome prediction for renal cell carcinoma (RCC) remains controversial and although many parameters have been tested for prognostic significance, few of these have achieved widespread acceptance in clinical practice. ${ }^{1-3}$

In 1997, the utility of putative prognostic parameters for RCC was evaluated by a workgroup convened as part of the Rochester Renal Cell Carcinoma Consensus Conference. ${ }^{4}$ At this meeting

Correspondence: Professor B Delahunt, MD, FRCPA, FRCPath, Department of Pathology and Molecular Medicine, Wellington School of Medicine and Health Sciences, University of OtagoWellington, PO Box 7343, Wellington South, New Zealand.

E-mail: bd@wnmeds.ac.nz

Received 1 August 2008; accepted 8 September 2008 a wide variety of prognostic factors were evaluated according to the criteria of the College of American Pathologists Working Classification for Prognostic Markers. ${ }^{5}$ Of the numerous markers considered, only positive surgical margins, metastatic spread, pTNM stage, sarcomatoid architecture, tumor type, and tumor grade were classified as category 1 prognostic factors, being considered to be well supported in the literature and generally used in patient management. Of interest, no single tumorgrading system was specified by this working group as having prognostic significance and the category 1 classification was defined on the basis of the comparison of low- and high-grade tumors. Despite this endorsement of both tumor stage and grade as useful prognostic markers, a number of questions remain regarding the application of these parameters 
in clinical practice and in particular, the validity of the grading systems currently employed for RCC has been questioned. ${ }^{3}$

\section{Tumor grading}

\section{The evolution of renal cell carcinoma grading}

The concept of classifying tumors according to the degree of differentiation was first proposed by Broders in 1920 in his study of squamous-cell carcinoma of the lip. ${ }^{6}$ These criteria were applied to a series of renal tumors by Hand and Broders in $1932 .^{7}$ In this study four grades were defined based on the criteria of Broders (1920), with tumors divided according to the percentage of the tumors showing cellular differentiation. Four grades were defined ranging from grade $1-75 \%$ to almost $100 \%$ differentiation, to grade $4-0$ to $25 \%$ differentiation, and tumors studied included renal neuroblastoma, lymphosarcoma, and renal pelvic squamous-cell carcinoma, as well as clear cell RCC and papillary RCC. In practice, few RCC contain differentiated foci that resemble parent tissue and as a consequence Hand and Broder's grading system is unworkable for these tumors. A more rational approach was proposed by Griffiths and Thackray in 1949, who developed a composite grading system that included evaluation of cell morphology, tumor architecture, degree of nuclear pleomorphism, and mitotic rate. ${ }^{8}$ Three grades were defined and in their series, 5-year survivals ranged from 72 (grade 1 ) to $28 \%$ (grade 3 ).

Since the publication of Griffith and Thackray's study eight additional composite grading systems for RCC have been proposed, with classification criteria including tumor architecture, cellular differentiation, nuclear features, and the presence or absence of tumor necrosis ${ }^{9-16}$ (Table 1). In addition to these, several other grading systems have been formulated, however, rather than concentrating of cellular differentiation they include a variety of morphologic parameters that, in addition to histologic features, included tumor circumscription, and infiltration into adjacent structures, (summarized in Arner et $a l^{11}$ ).

A recurring feature of the various composite grading systems for RCC is their failure to stratify the importance of the grading criteria, which implies that each feature should be given an equal weighting when tumors are assessed. This assumes that each of the grading criteria will evolve in parallel through each of the grades and no attempt has been made to validate this by the authors. More recent studies have, in fact, suggested that this is not the case as, for example, spindle cell or sarcomatoid RCC, the most extreme degree of dedifferentiation, does not necessarily exhibit a pronounced degree of nuclear pleomorphism. ${ }^{17}$ A number of the composite grading systems are also hampered by limited defining criteria, with grading based on what was described as overall microscopic appearance, or

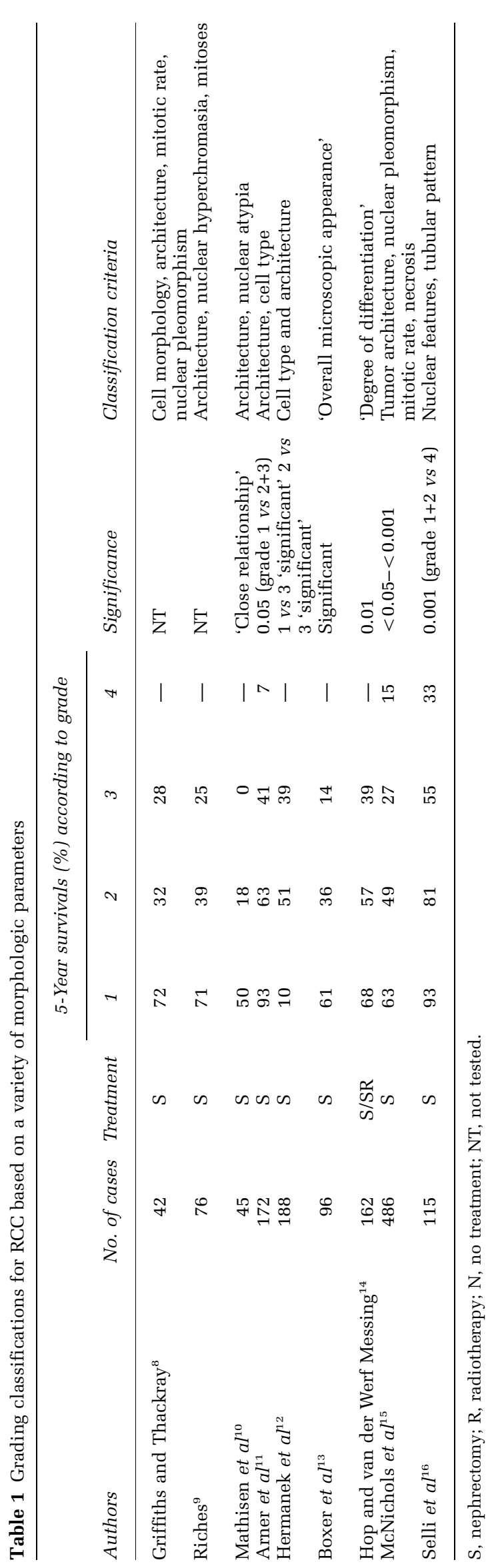


degree of differentiation, thus promoting interobserver error. These errors are compounded by a failure of authors to clearly state if grading should be based on the highest grade, the average grade, or the predominant grade present within the tumor. In the majority of studies significance testing was undertaken with outcomes being shown to be significantly different between grades. In some studies, however, significance was only achieved when lower grades were pooled and tested against the highest defined grade.

In an attempt to overcome the difficulty of assessing multiple features of a tumor simultaneously, Myers et $a l^{18}$ introduced a grading system based on the degree of anaplasia without further defining grading criteria. This concept was refined by Skinner et $a l^{19}$ who demonstrated a significant difference in survivals for their four-tier grading system. Since the publication of Skinner's study nine additional nuclear grading systems have been proposed $^{13,17,20-26}$ (Table 2). Of these only one defines the area of tumor that should be assessed for grading purposes, basing this on the high-power field showing the highest nuclear grade. ${ }^{26}$ In addition, few clearly state if grading should be based on the greatest or average degree of nuclear pleomorphism present.

Despite the reported prognostic significance of many of the proposed composite and nuclear grading systems, some fail to predict the survival in the majority of cases adequately. In most grading systems high- and low-grade tumors are associated with an unfavorable or favorable prognosis, respectively; however, the majority of RCCs are, in these studies, classified into the intermediate or middle grades where outcome is less predictable and in some classifications there was a lack of statistical significance when survivals of patients with tumors in these intermediate grades were compared.

\section{Fuhrman Grading}

In most survival studies undertaken over the past 25 years, grading has been based on the criteria of the Fuhrman classification $^{22}$ (Table 3). This has gained widespread acceptance in clinical practice with Fuhrman's 1982 report being one of the most cited studies in the renal cancer literature. Despite this acceptance, the utility of the Fuhrman grading has been questioned and studies have highlighted problems relating to the application of the grading system as initially proposed. ${ }^{2,17,27}$

A significant event relating to our assessment of the behavior of RCC has been the understanding that this is not a single tumor type, but rather a variety of tumors that are derived from different parts of the nephron, having differing genetics, morphologic features and clinical behaviors. The recommendations of the Heidelberg and Rochester Consensus Conferences $^{28,29}$ and more recently the WHO Classi-

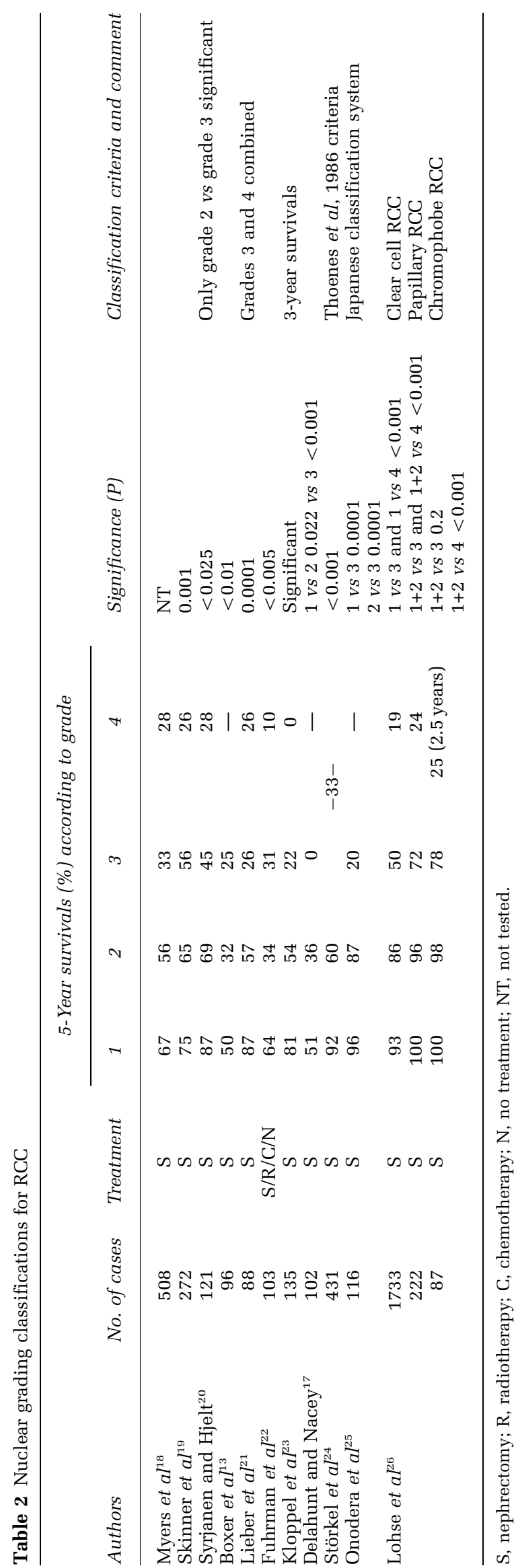


Table 3 Defining features of the Fuhrman grading classification ${ }^{22}$

\begin{tabular}{lll}
\hline & Nuclear diameter & Nuclear shape \\
\hline Grade 1 & Small $(\sim 10 \mu \mathrm{m})$ & Round, uniform \\
Grade 2 & Larger $(\sim 15 \mu \mathrm{m})$ & Irregularities in outline \\
Grade 3 & Even larger $(\sim 20 \mu \mathrm{m})$ & Obvious irregular outline \\
Grade 4 & As for grade 3 with bizarre often multilobed nuclei spindle cells \\
\hline
\end{tabular}

Table 4 Distribution of Fuhrman grade and association of grading with survival for published series of RCC

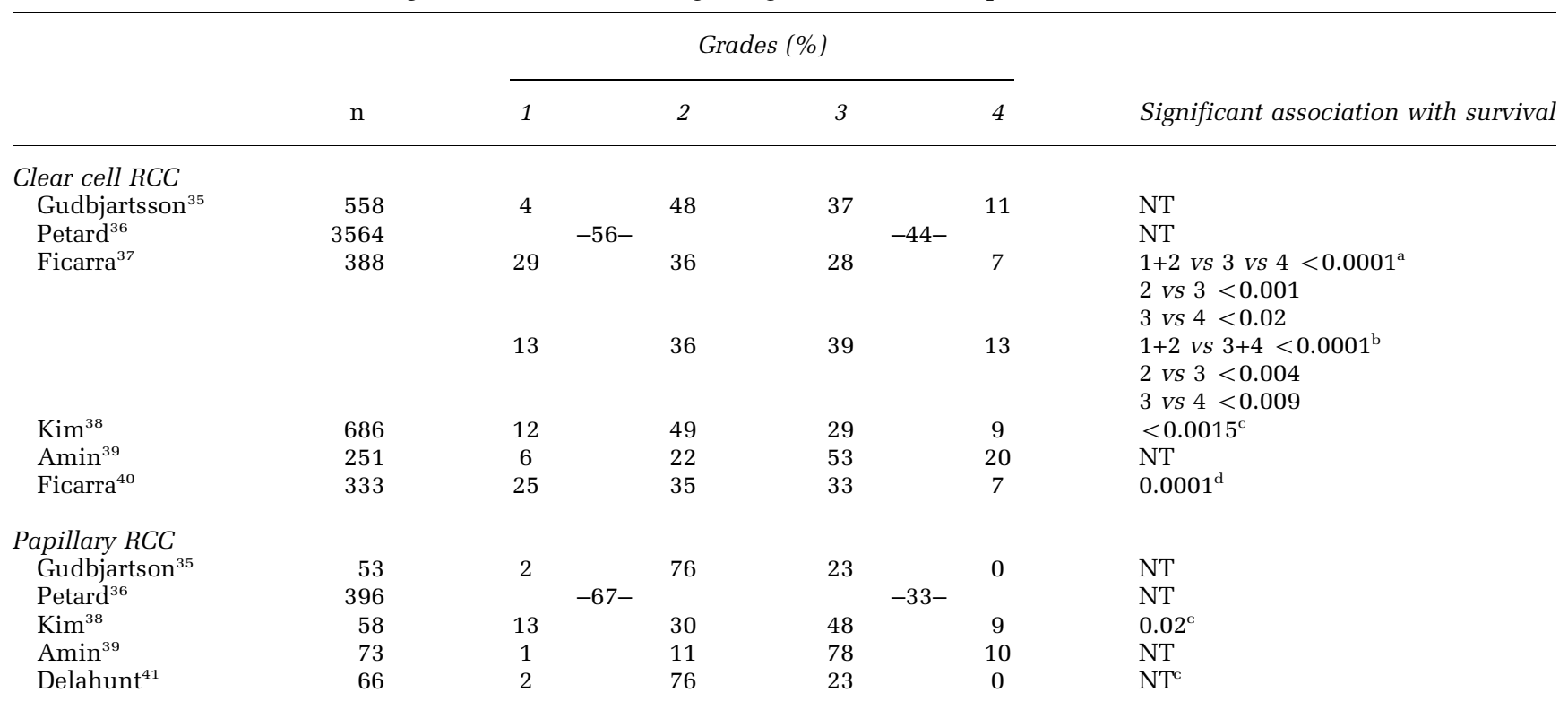

NT, nontested as univariate parameters for individual RCC subtypes; RCC, renal cell carcinoma.

${ }^{\mathrm{a}}$ Reported grade.

${ }^{\mathrm{b}}$ Reviewed grade.

${ }^{\mathrm{C}}$ Not significant in multivariate analysis that included tumor stage.

${ }^{\mathrm{d}}$ Retains significance on multivariate analysis that included tumor stage.

fication of Renal Parenchymal Tumors, ${ }^{30}$ have led to a reevaluation of a variety of prognostic parameters for RCC, including tumor grade. As originally defined, the Fuhrman grading system was based on a composite series of tumors containing a variety of RCC subtypes, including clear cell and papillary RCC. Survival analysis of cases in the original report showed that grading was significantly related to outcome over a 5-year follow-up period when grade 2 and 3 tumors were collapsed into a single grade, which consisted $76 \%$ of cases in the series. Similarly, a number of studies that have investigated the prognostic significance of Fuhrman grading, among a variety of morphologic parameters have contained a mixed series of renal epithelial tumors, some even including oncocytomas. ${ }^{31-34}$ These studies are of limited validity as they fail to take into account the confounding influence of the prognostic significance of tumor type.

In recent studies following the publication of the Heidelberg/Rochester Classification, in which Fuhrman grading was tested against survival for large series of tumors divided according to RCC subtype, varying results were achieved (Table 4). In studies limited to clear cell RCC, where statistical analysis was undertaken, significant differences in survival were demonstrated between all grades or combined grades 1 and 2 , grade 3 and 4 tumors. ${ }^{37,38,40}$ These data, however, did not always retain significance on multivariate analysis against a variety of staging parameters (local extension nodal and distant metastases). ${ }^{38,40}$ In addition, Fuhrman grading has been shown to correlate with outcome for pT1 clear cell RCC, irrespective of tumor size although tumors were grouped (G1+G2 vs G3 + G4) for statistical analysis. ${ }^{42}$ For papillary RCC there are little data regarding the prognostic significance of Fuhrman grading although in two series grading did not achieve a significant relationship with outcome on multivariate analysis that included tumor stage. ${ }^{38,41}$ Results from studies on chromophobe RCC are even less conclusive largely because of the small number of tumors available for study. In one series Fuhrman grading was shown to correlate with survival 
although significance was lost on multivariate analysis. ${ }^{36}$

The Fuhrman grading system is hampered by a number of factors. As originally defined, the system is based on the simultaneous assessment of three features-nuclear size, nuclear pleomorphism, and nucleolar prominence, without any objective evidence of concordance between these parameters. In cases where there is a discrepancy between parameters no recommendation is provided to indicate which grading parameter should be given the most weight when assigning a grade in individual cases. Some pathologists attempt to overcome the problem by confining grading to assessment of nucleolar prominence alone, and thus neglect the other two parameters defined in the Fuhrman grading classification. ${ }^{3}$

In the Fuhrman system the criteria for nuclear pleomorphism are poorly defined and features relating to nucleolar prominence are subject to interobserver error. In particular many nucleoli visible at $\times 400$ magnification are visible at $\times 100$, and the decision as to whether these are sufficiently prominent at the lower magnification to justify an assignment of grade 3 is left to the discretion of the examining pathologist. The uncertainty relating to the assessment of these criteria is reinforced by the finding that there is only fair to at-best moderate interobserver and intraobserver reproducibility for Fuhrman grading, ${ }^{43-45}$ and interobserver reproducibility of the Fuhrman system has been shown to be inferior to the nuclear grading system of Syrjänen and Hjelt. ${ }^{46}$ Further evidence of the poor reproducibility of Fuhrman grading may also be inferred from the observation that the number of cases within each grade varies widely between reported series (Table 4).

Recent investigations have separately assessed the validity of each of the defining criteria of the Fuhrman grading classification for papillary and chromophobe RCC. ${ }^{47,48}$ For papillary RCC it was found that of the three parameters of the Fuhrman system, neither the morphometric measures of nuclear size nor pleomorphism correlated with outcome. Nucleolar prominence, based on the microscopic high-power field showing the greatest degree of nuclear pleomorphism was significantly associated with outcome on univariate analysis, although this was not independent of pT category or TNM stage. ${ }^{47}$ For chromophobe RCC not one of the three grading components was correlated with outcome, when tested separately, which raises questions as to the validity of Fuhrman grading for these tumors. ${ }^{48}$ Importantly, when tumors in both of these series were classified on the basis of nuclear size alone, utilizing the nuclear diameter cut points proposed by Fuhrman, then all tumors were classified as grade 1, whereas assessment of focal nucleolar prominence on its own showed $58 \%$ of papillary RCC and $24 \%$ of chromophobe RCC to exhibit grade 3 characteristics.

\section{Sarcomatoid and Rhabdoid Differentiation}

Defined as a diagnostic category in the 1981 and 1998 WHO classifications, sarcomatoid carcinoma is now considered an extreme form of dedifferentiation of RCC. ${ }^{49}$ In the Fuhrman grading classification the presence of spindle cells is feature of grade 4 tumors and outcome studies confirm a poor prognosis consistent with a high-grade malignancy, with disease-specific survivals at 2, 3, and 5 years of 28.6-37, 19.1-32, and 14.5-22\% being reported. ${ }^{49-52}$

Survival of patients with sarcomatoid RCC is further influenced by stage as in one series patients with localized disease at presentation had a median survival of 17 months compared to those with regional or distal metastases, whose survivals were 7.7 and 7 months, respectively. ${ }^{53}$ In the majority of series the proportion of the sarcomatoid component of the tumor did not correlate with outcome, however, one study did report a weakly significant association with survival when tumors were divided according to a sarcomatoid component of $\leq 50$ and $>50 \%{ }^{51}$

The genetic abnormalities associated with the evolution of a spindle-cell morphology are poorly understood, although losses of chromosome 4q, 6q, $8 p, 9,13 q, 14$ and $17 p$, and gains of chromosome 5, 12 , and 20 have been noted. ${ }^{54,55}$ In a separate study gains of chromosome 1, 2, 6, 10, and 17 have been demonstrated for chromophobe sarcomatoid carcinoma. ${ }^{56}$ There is also evidence to indicate that carcinomas evolve into sarcomatoid carcinomas through a variety of mutational steps as collagen expression of carcinomas showing early spindle-cell change differs from that of well-developed sarcomatoid carcinomas. ${ }^{57}$ This would appear to validate the suggestion that for prognostic assessment early spindle-cell change should not be classified as sarcomatoid carcinoma. ${ }^{51}$

The presence of rhabdoid differentiation, characterized by tumor cells with a large irregular nucleus, prominent nucleolus, and abundant eosinophilic cytoplasm, has been recognized in the major subtypes of RCC and has been associated with a poor prognosis. ${ }^{58-60}$ In particular, patients with tumors containing foci of rhabdoid differentiation are twice as likely to present with extrarenal tumor spread, ${ }^{58}$ whereas $71 \%$ of patients developed metastases with a mean follow-up of 4.5 months. ${ }^{59}$ Within 2 years it was also noted that $43 \%$ of patients in this series had died, with a mean survival interval of 8 months. ${ }^{59}$

Rhabdoid areas in RCC satisfy the nuclear and nucleolar criteria for Fuhrman grade 4 and although most tumors are associated with grade 4 RCC, $3 \%$ of grade 2 and $9 \%$ of grade 3 tumors also show rhabdoid differentiation. ${ }^{58}$ The proportion of rhabdoid cells in these tumors varied from 1 to $90 \%$, however, this does not appear to have any influence on outcome. ${ }^{59}$ 


\section{Conclusions}

Although the poor prognosis of tumors showing sarcomatoid dedifferentiation or rhabdoid morphology, which would be classified as grade 4 tumor according to the criteria of Fuhrman, is well recognized, Fuhrman grading of the various subtype of RCC remains controversial. The Grading Workgroup of the Rochester Consensus Conference ${ }^{27}$ noted that most existing grading systems in experienced hands have prognostic significance, especially for low-stage tumors. Despite this they concluded that an ideal grading system for RCC has yet to be developed. It was recommended that grading should be based on nuclear criteria and further that any grading system should probably consist of three tiers. They further noted that the area of tumor that should be assessed for grading purposes has yet to be defined.

Recent results indicate that for papillary RCC grading should be based on nucleolar prominence only and that this should be assessed from the highpower field in the tumor showing the greatest degree of nuclear pleomorphism. These data are not independent of TNM stage, but stratify outcome within each staging category. None of the proposed grading systems for RCC has been validated for chromophobe RCC, and in particular it would appear that Fuhrman grading is inappropriate for this tumor type. Beyond this the various grading criteria of the Fuhrman classification have yet to be formally assessed separately and validated for the other subtypes of renal epithelial malignancy, including clear cell RCC.

\section{Tumor staging}

\section{Early Staging Classifications}

Tumor stage is acknowledged as the most powerful prognostic indicator for RCC ${ }^{16,61}$ and in early reports metastatic spread, infiltration of the renal vein and perirenal fat invasion were noted as being associated with a poor outcome. ${ }^{8}$ The first formalized staging system for renal tumors was that of Flocks and
Kadesky published in $1958^{62}$ (Table 5). A similar classification was proposed by Petkovic in $1959,{ }^{63}$ who placed greater emphasis on the features of intrarenal tumors by dividing Flocks and Kadesky's stage 1 tumors into stages 1 and 2 of his new system. Robson in $1963^{64}$ and $1969,{ }^{65}$ modified these two staging systems, subdividing localized extrarenal invasion (stage 3) according to the structures involved. In subsequent survival studies the prognostic significance of the Robson staging system has been validated, although significant differences in survival between each of the staging categories was not always observed. ${ }^{2}$ Of relevance, some reports have shown that survivals for stage 1 and stage 2 tumors and stage 2 and stage 3 tumors were not significantly different, whereas in a number of studies renal vein infiltration was found not to be a significant prognostic feature. ${ }^{2}$

\section{UICC/AJCC Classification}

In 1978 the Union Internationale Contre le Cancer (UICC) $^{66}$ and the American Joint Committee for Cancer Staging and End Results Reporting (AJCC) proposed the TNM staging system for RCC (Table 6). Intrarenal tumors were classified into stages 1 and 2 on the basis of a subjective assessment of tumor size. Tumors confined to Gerota's fascia (Robson stage 2) were grouped into stage 3 along with those tumors showing vascular invasion, which themselves were subdivided according to the vessels involved, ranging from microscopic invasion of the renal vein to tumor thrombus in the vena cava. This 1978 classification has been validated in studies, ${ }^{67,68}$ although in some investigations not all categories showed independent prognostic significance and in particular the importance of microscopic infiltration of the renal vein has been questioned. ${ }^{69}$

The main difference between the Robson and TNM classifications is that the Robson system emphasizes those tumors that show extrarenal spread (stages 2-4). The TNM system is more focused on intrarenal tumors, in an attempt to predict outcome in those patients who have undergone attempted curative surgery.

Table 5 Comparison of early staging systems for RCC

\begin{tabular}{|c|c|c|c|}
\hline & Flocks and Kadesky ${ }^{62}$ (cases/survival) $^{\mathrm{a}}$ & Petkovic $^{63}$ (cases/survival) $^{\mathrm{b}}$ & Robson et $\mathrm{al}^{65}$ (cases/survival) $^{\mathrm{a}}$ \\
\hline 1 & Limited to renal capsule $(76 / 46 \%)$ & Intrarenal encapsulated solitary (12/75\%) & Confined to kidney (33/66\%) \\
\hline 2 & $\begin{array}{l}\text { Renal pedicle and/or renal fat invasion } \\
(59 / 37 \%)\end{array}$ & $\begin{array}{l}\text { Intrarenal extension, tumor capsule } \\
\text { penetration }(22 / 55 \%)\end{array}$ & $\begin{array}{l}\text { Confined to Gerota's fascia } \\
(15 / 64 \%)\end{array}$ \\
\hline 3 & Regional lymph node involvement (33/9\%) & $\begin{array}{l}\text { Invasion of renal capsule and/or renal vein } \\
\text { and/or regional lymph nodes }(46 / 4 \%)\end{array}$ & $\begin{array}{l}\text { 3a: Gross renal vein invasion } \\
\text { 3b: Lymph node invasion } \\
\text { 3c: Combined a and b }(27 / 42 \%)\end{array}$ \\
\hline 4 & Distal metastases (116/3.5\%) & Distant metastases $(18 / 6 \%)$ & $\begin{array}{l}\text { 4a: Adjacent organs involved } \\
\text { 4b: Distant metastasis }(12 / 11 \%)\end{array}$ \\
\hline
\end{tabular}

\footnotetext{
${ }^{a}$ 5-year survival (\%).

${ }^{\mathrm{b}}$ Survivors (length of survival not stated).
} 
Table 6 Evolution of the UICC/AJCC primary tumor staging category for RCC

\begin{tabular}{|c|c|c|c|}
\hline $\begin{array}{l}\text { UICC TNM }(1978)^{66} T \text {-primary } \\
\text { tumor }\end{array}$ & $\begin{array}{c}\text { UICC TNM }(1987)^{71} T \text {-primary } \\
\text { tumor }\end{array}$ & $\begin{array}{c}\text { UICC TNM }(1997)^{73} T \text {-primary } \\
\text { tumor }\end{array}$ & $\begin{array}{c}\text { UICC TNM }(2002)^{74} \mathrm{~T}-\text { primary } \\
\text { tumor }\end{array}$ \\
\hline Intrarenal (small) & $\mathrm{T} 1 \leq 2.5 \mathrm{~cm}$, limited to kidney & $\mathrm{T} 1 \leq 7 \mathrm{~cm}$, limited to kidney & $\begin{array}{l}\mathrm{T} 1 \mathrm{a} \leq 4 \mathrm{~cm} \\
\mathrm{~T} 1 \mathrm{~b}>4-\leq 7 \mathrm{~cm}\end{array}$ \\
\hline Intrarenal (large) & $\mathrm{T} 2>2.5 \mathrm{~cm}$, limited to kidney & $\mathrm{T} 2>7 \mathrm{~cm}$, limited to kidney & $\mathrm{T} 2>7 \mathrm{~cm}$ \\
\hline $\begin{array}{l}\text { T3a: Confined to Gerota's fascia } \\
\text { T3cap: Involves renal capsule } \\
\text { T3pel: Involves renal pelvis } \\
\text { T3m: Involves renal vein } \\
\text { (microscopic) }\end{array}$ & $\begin{array}{l}\text { T3a: Invades adrenal gland or } \\
\text { perinephric tissues, but not } \\
\text { beyond Gerota's fascia }\end{array}$ & $\begin{array}{l}\text { T3a: Invades adrenal gland or } \\
\text { perinephric tissues but not } \\
\text { beyond Gerota's fascia }\end{array}$ & $\begin{array}{l}\text { T3a: Invades adrenal gland, } \\
\text { perirenal tissues including renal } \\
\text { sinus (peripelvic) fat }\end{array}$ \\
\hline T3b: Involves renal vein & $\begin{array}{l}\text { T3b: Grossly into renal vein or } \\
\text { vena cava }\end{array}$ & $\begin{array}{l}\text { T3b: Grossly into renal vein or } \\
\text { vena cava below diaphragm }\end{array}$ & $\begin{array}{l}\text { T3b: Into renal vein, including } \\
\text { segmental (muscle containing) } \\
\text { branches or cava below } \\
\text { diaphragm }\end{array}$ \\
\hline $\begin{array}{l}\text { T3c: Involves renal vein and } \\
\text { infradiaphragmatic vena cava }\end{array}$ & & $\begin{array}{l}\text { T3c: Grossly into vena cava } \\
\text { above diaphragm }\end{array}$ & T3c: Vena cava above diaphragm \\
\hline $\begin{array}{l}\text { T4a: Invasion of adjacent } \\
\text { structures } \\
\text { T4b: Supradiaphragmatic vena } \\
\text { cava infiltration }\end{array}$ & $\begin{array}{l}\text { T4: Invades beyond Gerota's } \\
\text { fascia }\end{array}$ & $\begin{array}{l}\text { T4: Invades beyond Gerota's } \\
\text { fascia }\end{array}$ & $\begin{array}{l}\text { T4: Invades beyond Gerota's } \\
\text { fascia }\end{array}$ \\
\hline
\end{tabular}

AJCC, American Joint Committee for Cancer Staging and End Results Reporting; UICC, Union Internationale Contre le Cancer.

\section{Tumor Size (TNM Categories T1 and T2)}

In the 1978 edition of the TNM classification, tumors localized to the kidney were grouped into category $\mathrm{T} 1$ or $\mathrm{T} 2$ on the basis of size and the presence or absence of distortion or enlargement of the kidney and/or collecting system; however, no defining size cut points were specified. Follow-up studies showed that the survival for T1 tumors was similar to that for T2 tumors, ${ }^{16,70}$ which probably reflected the subjective nature of T1/T2 categorization of tumors. In other studies undertaken to validate the $1978 \mathrm{TNM}$ classification, no attempt was made to divide tumors according to size for survival analysis. ${ }^{69}$

The UICC/AJCC TNM staging classification was modified in 1987, 1993 (supplement), 1997, and $2002 .{ }^{71-74}$ In these later editions of the TNM system, cut points were defined for stage 1 and stage 2 tumors and in subsequent editions modifications were made to these sizes. In the 1987 edition the cut point was at $2.5 \mathrm{~cm}$ as it was considered that tumors smaller than this were unlikely to have metastasized before surgery. This was, however, found to be lacking in discrimination as few tumors are $<2.5 \mathrm{~cm}$, with this category comprising 1 to $8 \%$ of reported series. ${ }^{75}$ In the 1993 supplement the T2 category was expanded into four subcategories (T2a $>2.5-5 \mathrm{~cm}$, T2b $>5-7.5 \mathrm{~cm}, \mathrm{~T} 2 \mathrm{c}>7.5-10 \mathrm{~cm}$, and $\mathrm{T} 2 \mathrm{~d}>10 \mathrm{~cm}$ ) and in 1997, this subclassification was replaced with the recommendation that the T1/T2 cut point be $7 \mathrm{~cm}$. In follow-up studies, this cut point was found not to adequately stratify metastasizing and non-metastasizing tumors and in 2002 the T1 category was subdivided into T1a and $\mathrm{T} 1 \mathrm{~b}$, with a cut point at $4 \mathrm{~cm}$. This was proposed as it was considered that tumors $\leq 4 \mathrm{~cm}$ were likely to be organ confined and being localized were thus suitable for treatment by partial nephrectomy.

Numerous investigations into the prognostic significance of tumor size for localized RCC have been reported, and in separate studies cut points of $4,4.5$, $5,5.5,6.5,7.5$, and $10 \mathrm{~cm}$ have been shown to have prognostic significance. ${ }^{42,76-80}$ These findings are not surprising as detailed analysis of tumor size as a continuous variable has shown that the probability of death increases with tumor size $(3.51 \times$ for each doubling of tumor size). ${ }^{81}$ As a consequence any arbitrary cut point will likely be significantly associated with survival providing that the sample size is sufficiently large.

\section{Regional Spread of Tumor (TNM Category T3)}

Tumors categorized as T3 have been noted to have a variable outcome, and in particular, no differences in outcomes for T2 and T3a categories have been reported. ${ }^{82}$ In this study it was noted that, as defined, the T3a category consisted of a diverse group, ranging from small tumors with favorable outcome to large tumors that subsequently recurred. It was further shown that if perirenal invasion was ignored and tumors grouped according to size alone (T1a $\leq 4 \mathrm{~cm}, \mathrm{~T} 1 \mathrm{~b}>4-\leq 7 \mathrm{~cm}, \mathrm{~T} 2 \mathrm{a}>7-\leq 10 \mathrm{~cm}$, and $\mathrm{T} 2 \mathrm{~b}>10 \mathrm{~cm}$ ) a greater correlation with outcome was obtained. In other studies, however, renal sinus and perirenal fat invasion has been shown to be of prognostic significance independent of tumor size. ${ }^{83}$

In the 1978 TNM classification, tumors infiltrating the renal pelvis were categorized as T3pel, however, this was deleted from subsequent editions. In recent studies the prognostic significance of infiltration 
into the tissues of the renal sinus has been specifically addressed and shown to predict outcome. ${ }^{84}$ Separate reports have also shown infiltration of lymphatics and small blood vessels in the renal sinus to have prognostic significance. ${ }^{85,86}$ From these studies it appears that tumor size predicts renal sinus invasion, as this is seen in $97 \%$ of tumors $>7 \mathrm{~cm}$ in diameter. These observations have been confirmed for clear cell RCC, papillary RCC, and chromophobe RCC, although involvement of the renal sinus was found to be less frequent in the latter two tumor subtypes. ${ }^{87}$ This study also confirmed that invasion of the renal sinus was associated with a less favorable outcome when compared to infiltration of extrarenal sinus perirenal fat, although these findings have been challenged as similar survivals have also been reported for perirenal and renal sinus fat invasion. ${ }^{88}$ Despite this conflicting report, renal sinus invasion appears to have significance as a prognostic parameter and this feature has been added to the T3a category of the UICC classification. As the importance of this parameter has been only recently described, retrospective studies must rely on material collected at a time when no emphasis was made on adequate sampling of the renal sinus. For this reason these studies should be treated with caution and confirmation as to the prognostic importance of renal sinus invasion must be sought from tumor series collected prospectively.

The T3 category of the 1978 TNM classification was divided into five subcategories based on renal capsule and vascular invasion, without reference to infiltration of the adrenal gland. This omission was rectified in the 1987 edition of the classification, with direct adrenal gland invasion being classified as T3a along with invasion into perirenal tissues, but not beyond Gerota's fascia.

In reported series, direct infiltration of the ipsilateral adrenal gland is rarely encountered and is seen in approximately $0.8-2.5 \%$ of patients treated by radical nephrectomy. ${ }^{89,90}$ In the 2002 edition of the TNM classification both direct infiltration of the adrenal gland and infiltration into perirenal fat remain classified as category T3a. From published series this would appear inappropriate as patients with direct extension of tumor into the adrenal gland have been shown to have a poor prognosis, with 5-year survival of $20.2 \%$ being similar to that for pT4 tumors. ${ }^{91,92}$ Direct spread of tumor to the adrenal is differentiated from metastatic spread, which is currently included in category pT4 of the TNM system. Adrenal metastases are seen in up to 10\% of RCC in surgical series and $29 \%$ of RCC at post mortem. The prognosis of metastatic spread to the adrenal gland is, however, not as poor as that resulting from infiltration of tumor to other organs, as in large series the presence of solitary adrenal metastasis was associated with 5- and 10-year survivals of 61 and 31\%, respectively. This compares with survivals of 19 and $16 \%$ for patients with combined adrenal and extraadrenal metastatic spread of tumor. ${ }^{93}$

Microscopic invasion of the renal vein was omitted from the 1987 edition of the TNM classification and vascular involvement was grouped according to invasion of the renal vein or the vena cava (T3b). In 1997, the T3b category was further subdivided into tumor extending into renal vein or the vena cava below the diaphragm (T3b) or into vena cava above the diaphragm (T3c).

There are limited studies that investigate the prognostic significance of microvascular invasion of the renal vein by RCC, although recent evidence suggests that this may have prognostic utility. In a small series of mixed histology T1 and T2 tumors, microvascular invasion was shown to correlate with outcome and this was found to be independent of $\mathrm{T}$ category, grade and perirenal fat invasion. ${ }^{94}$ In earlier studies the presence of microvascular invasion of the renal vein was also found to be associated with a significantly higher rate of tumor recurrence following nephrectomy. ${ }^{95,96}$ Microvascular invasion has also been shown to correlate with the development of metastases and with survival, independent of tumor size, primary tumor category-pT1 to pT3, and Fuhrman grade. ${ }^{97}$

There is continuing debate as to the prognostic significance of the level of tumor thrombus within the renal vein and vena cava. In 2004, the Mayo classification of macroscopic venous invasion in RCC was proposed that defined five levels of thrombus, ie 0-within the renal vein, I-within the inferior vena cava $<2 \mathrm{~cm}$ from its confluence with the renal vein, II-within the inferior vena cava $>2 \mathrm{~cm}$ above the confluence but below the hepatic vein, III-within the intrahepatic vena cava, and IV-within the vena cava above the diaphragm or in the atrium. $^{98}$ In subsequent studies conflicting results as to the prognostic significance of this classification have been reported, with some studies validating the classification, ${ }^{99-100}$ whereas others have shown that the level of tumor thrombus beyond the renal vein does not influence survival. ${ }^{101-105}$ To predict the outcome more accurately in locally advanced disease, additional parameters have been proposed to further stratify tumors showing vascular invasion. In particular, the poor prognosis associated with perirenal fat, adrenal and Gerota's fascia infiltration has led to the incorporation of those features into a proposed modification of pT3-4 criteria. ${ }^{92,101,106}$ In this modification, which is based on international multicenter studies, cases have been grouped according to the presence of tumor thrombus within the renal vein or infradiaphragmatic vena cava, or the presence of perirenal fat invasion (group 1), fat invasion with either renal vein or infradiaphragmatic vena cava thrombus, or adrenal gland invasion (group 2) and adrenal involvement with either renal vein or infradiaphragmatic vena cava thrombus, or supradiaphragmatic vena cava thrombus or Gerota's fascia invasion 
(group 3) with 5-year survivals for each group being shown to be 61,35 , and $12.9 \%$, respectively. ${ }^{106}$ Although this would seem to be a promising advance, further studies and necessary to validate this proposed modification of the TNM system.

\section{Lymph Node Metastases}

The poor prognosis associated with the presence of lymph node metastases was recognized in the early staging systems for RCC. In the Flocks and Kadesky classification, ${ }^{62}$ lymph node involvement was separated from infiltration of the renal fat and/or renal vein and was shown to have an outcome more favorable than that for patients with metastatic tumors. Outcome for these cases was further stratified by treatment, with $14 \%$ of patients who underwent surgery alive at 5 years compared with $0 \%$ in the nontreated group. Petkovic ${ }^{63}$ classified tumors showing renal capsule and renal vein involvement along with lymph node infiltration as stage 3, although the 5-year survival of this group did not differ from those with metastatic disease. In Robson's classification, ${ }^{65}$ which was based on patients who had undergone lymphadenectomy, lymph node infiltration was associated with a 5 -year survival of $35 \%$ compared with $45 \%$ for tumors with renal vein involvement and $11 \%$ for patients with distant metastases.

In the UICC/AJCC TNM classifications, the presence or absence of regional node involvement is separated from the T-staging category and in the 1978 classification ${ }^{66}$ tumors were categorized into five groups: N0—no nodal involvement, N1-single ipsilateral node involved, N2-multiple regional, contralateral, or bilateral nodes involved, N3-fixed regional nodes, and N4-juxtaregional lymph nodes involved. For the 1987 edition of the classification, ${ }^{71}$ the $\mathrm{N}$ category was redefined according to criteria based on the size of the involved lymph node (Nono regional lymph node metastases, N1-single lymph node involved $\leq 2 \mathrm{~cm}$ diameter, N2-single lymph node $>2$ to $<5 \mathrm{~cm}$ in diameter or multiple lymph nodes $<5 \mathrm{~cm}$ in diameter involved, and N3involved lymph node(s) $>5 \mathrm{~cm}$ in diameter). The N1-3 categories of the fourth (1987) edition of the TNM classification were reduced to two categories in the fifth edition (1997), ${ }^{73}$ with cases divided according to the presence of metastases in a single regional lymph node (N1) or in multiple nodes (N2) and these criteria were retained in the sixth edition (2002) of the classification. ${ }^{74}$

Despite the detailed classification of lymph node metastases in the $\mathrm{N}$ category of the 1978 and 1987 editions of the TNM system, most studies that focus on the prognostic significance of lymph node involvement restrict their analyses to the absence (No) and presence $(\mathrm{N}+)$ of nodal disease. In one, large series nodal infiltration was seen in $18 \%$ of cases and irrespective of $\mathrm{T}$ category, the 5-year survival rate of patients with No tumors was found to be significantly different from those with $\mathrm{N}+$ tumors, being 74 and $10 \%$, respectively. ${ }^{16}$ Giuliani et $a l^{107}$ reported a 5 -year survival rate of $52 \%$ for $\mathrm{N}+$ tumors with no evidence of extrarenal metastases in their series. This rate was similar to that of patients with pT3N0M0 tumors and was significantly higher than the $7 \%$ observed for patients with distant metastases. ${ }^{107}$ In this study they also found that the number of involved nodes ( $1 \mathrm{vs}>2$ nodes) did not correlate with outcome. In later survival studies nodal involvement (N0 vs N1-3) was found to confer an unfavorable prognosis and this was shown to retain significance along with patient age and pT category, on multivariate analysis. ${ }^{108}$ In a further study utilizing the criteria of the 1987 TNM classification, no difference in survival was demonstrated between $\mathrm{pN} 1$ and $\mathrm{pN} 2$ categories following extensive lymphadenectomy, with 5 -year survivals of 32 and $38 \%$ respectively, although the 5-year survival for patients with pN3 disease was markedly decreased at only $6 \% .^{109}$

More recently, significant differences in survivals for No and N + tumors have been reported, with the risk of mortality increasing with an increasing numbers of involved lymph nodes. ${ }^{110}$ In view of this, it is of interest that the number of $\mathrm{N}+$ nodes has been shown to be higher in those cases where greater numbers of lymph nodes are sampled and it has been recommended that $>12$ nodes be examined for staging purposes. ${ }^{111}$

In validation studies of the $\mathrm{N}$ category of the 2002 TNM classification, it was found that there was no difference in the survival rate of $\mathrm{pN} 1$ and $\mathrm{pN} 2$ tumors at 5 years follow-up (20 and 17\%, respectively). ${ }^{112}$ When cases were divided at $\leq 4$ and $>4$ involved nodes, the difference in survival between the two groups was significant. It was also shown that survival decreased with an increase in the percentage of involved nodes in each case, with significance being achieved at a cut point of $60 \%$.

Studies investigating the prognostic significance of lymph node metastases have almost entirely been restricted to series of mixed subtypes of RCC. Recently Margulis et $a l^{113}$ showed that patients with papillary RCC had a significantly increased risk of lymph node metastases when compared to patients with clear cell RCC. Interestingly the 5-year survival rate for papillary RCC $(65 \%)$ was significantly higher than that of clear cell RCC $(19 \%)$ in this series. This highlights the importance of classifying tumors according to subtype if meaningful results are to be obtained from studies investigating the prognostic significance of staging parameters.

The place of lymphadenectomy in the management of RCC has been widely debated. It has been shown that extensive lymphadenectomy confers no survival advantage in those patients where there is no clinical evidence of lymph node involvement by RCC. ${ }^{114,115}$ It has also been shown that although lymph node dissection is associated with increased survival in the short term-with an increased 
median survival of 5 months, this advantage was lost over a 5-year follow-up period. ${ }^{115}$

Lymph node metastases have been reported in 9$27 \%$ of cases of RCC, ${ }^{107}$ however, evaluation of the role of lymph node dissection in the management of patients with RCC is hampered by the relative scarcity of patients with lymph node metastases in the absence of extranodal tumor spread. This is highlighted by autopsy studies on patients with clinically unrecognized disease, where only $4.2 \%$ of cases were found to have metastases confined to lymph nodes. ${ }^{116}$ The identification of patients who are likely to have occult nodal metastases may be aided by the recent findings that focused on intrarenal lymphatic infiltration by tumor. In one series the presence of lymphatic infiltration was significantly associated with lymph node metastases whereas, in another, this was shown to be the only independent predictor of regional nodal involvement by tumor. ${ }^{117,118}$ In addition to these findings it is likely that the increased utilization of highresolution imaging will also provide an impetus for future research into the prognostic significance of nodal disease.

\section{Conclusions}

Over the past 30 years numerous evidence-based amendments have been made to the TNM staging system for RCC, in an attempt to more accurately predict patient outcome.

The prognostic significance of primary tumor size is well recognized and there is good evidence to suggest that tumor size also predicts infiltration of tumor into the renal sinus and is thus a dependent prognostic variable. Confirmatory studies as to the prognostic importance of renal sinus invasion are necessary and this emphasizes the necessity of careful dissection of the renal sinus to confirm or refute extrarenal spread of tumor and permit accurate assignment of pT category.

Regional spread of RCC is currently categorized as pT3, however, debate remains regarding the stratification of extent of spread of the various components of this category. Direct infiltration of the adrenal gland is a poor prognostic feature and in the current edition of the TNM system appears to be understaged. Vascular infiltration by RCC is associated with decreased patient survival rates. Recent studies have indicated that extent of spread of tumor within the renal venous outflow tract, in conjunction with the presence or absence of local spread into the adrenal gland or perirenal fat, gives a more accurate estimate of outcome than assessment of level of venous spread alone. There is also increasing evidence to indicate that microscopic infiltration of the renal vein is of prognostic significance and further studies are necessary to confirm if this should again be included as a component of pT3 category.
The poor prognosis associated with infiltration of lymph nodes by RCC has been confirmed in several studies. In early editions of the TNM classification, attempts were made to subdivide lymph node involvement into several subcategories without formal validation. More recently, studies have suggested that outcome is influenced by the number of involved lymph nodes, with the optimum cut point being four involved nodes. There is also evidence to suggest that the presence of intrarenal lymphatic infiltration is a predictor of the presence of tumor in regional lymph nodes.

The TNM staging classification for RCC continues to evolve and it is anticipated that large-scale multicentric studies will allow further refinement of its defining features.

\section{Disclosure/conflict of interest}

The author declares no conflict of interest.

\section{References}

1 Gelb AB. Renal cell carcinoma. Current prognostic factors. Cancer 1997;80:981-986.

2 Delahunt B. Histopathologic prognostic indicators for renal cell carcinoma. Semin Diagn Pathol 1998;15:68-76.

3 Delahunt B, Bethwaite PB, Nacey JN. Outcome prediction for renal cell carcinoma: evaluation of prognostic factors for tumours divided according to histological subtype. Pathology 2007;39:459-465.

4 Srigley JR, Hutter RVP, Gelb AB. Current prognostic factors-renal cell carcinoma. Cancer 1997;80:994-996.

5 Henson DE, Fielding LP, Grignon DJ, et al. College of American Pathologists Conference XXVI on clinical relevance of prognostic markers in solid tumors. Arch Pathol Lab Med 1995;119:1109-1112.

6 Broders AC. Squamous cell epithelioma of the lip. JAMA 1920;74:656-664.

7 Hand JR, Broders AC. Carcinoma of the kidney: the degree of malignancy in relation to factors bearing on prognosis. J Urol 1932;28:199-216.

8 Griffiths IH, Thackray AC. Parenchymal carcinoma of the kidney. Br J Urol 1949;21:128-151.

9 Riches EW. Factors in the prognosis of carcinoma of the kidney. J Urol 1958;79:190-195.

10 Mathiesen W, Muri O, Myhre E. Pathology and prognosis in renal tumors. Acta Clin Scand 1965;130: 303-313.

11 Arner O, Blanck C, von Schreeb T. Renal adenocarcinoma. Morphology-grading of malignancy-prognosis. A study of 197 cases. Acta Chir Scand (Suppl) 1965;346:7-52.

12 Hermanek P, Sigel A, Chlepas S. Histological grading of renal cell carcinoma. Eur Urol 1976;2:189-191.

13 Boxer RJ, Waisman J, Lieber MM, et al. Renal carcinoma: a computer analysis of 96 patients treated by nephrectomy. J Urol 1979;122:598-601.

14 Hop WCJ, var der Werf Messing BHP. Prognostic indexes for renal cell carcinoma. Eur J Cancer 1980; 16:833-840.

15 McNichols DW, Segura JW, DeWeerd JH. Renal cell carcinoma: long-term survival and late recurrence. J Urol 1981;126:17-23. 
16 Selli C, Hinshaw WM, Woodard BH, et al. Stratification of risk factors in renal cell carcinoma. Cancer 1983;52:899-903.

17 Delahunt B, Nacey JN. Renal cell carcinoma. Histological indicators of prognosis. Pathology 1987;19: 258-263.

18 Myers GH, Fehrenbaker LG, Kelalis PP. Prognostic significance of renal vein invasion by hypernephroma. J Urol 1968;100:420-423.

19 Skinner DG, Colvin RB, Vermilion CD, et al. Diagnosis and management of renal cell carcinoma. A clinical and pathologic study of 309 cases. Cancer 1971;28: 1165-1171.

20 Syrjänen K, Hjelt L. Grading of human renal adenocarcinoma. Scand J Urol Nephrol 1978;12:49-55.

21 Lieber MM, Tomera KM, Taylor WF, et al. Renal adenocarcinoma in young adults: survival and variables affecting prognosis. J Urol 1981;125:164-168.

22 Fuhrman SA, Lasky LC, Limas C. Prognostic significance of morphologic parameters in renal cell carcinoma. Am J Surg Pathol 1982;6:655-663.

23 Kloppel G, Knofel WT, Baisch H, et al. Prognosis of renal cell carcinoma related to nuclear grade, DNA content and Robson stage. Eur Urol 1986;12: 426-431.

24 Störkel S, Thoenes W, Jacobi GH, et al. Prognostic parameters in renal cell carcinoma-a new approach. Eur Urol 1989;16:416-422.

25 Onodera Y, Matsuda N, Ohta M, et al. Prognostic significance of tumor grade for renal cell carcinoma. Int J Urol 2000;7:4-9.

26 Lohse CM, Blute ML, Zincke H, et al. Comparison of standardized and non-standardized nuclear grade of renal cell carcinoma to predict outcome among 2042 patients. Am J Clin Pathol 2002;118:877-886.

27 Medeiros LJ, Jones EC, Aizawa S, et al. Grading of renal cell carcinoma. Cancer 1997;80:990-991.

28 Kovacs G, Akhtar M, Beckwith JB, et al. The Heidelberg classification of renal cell tumours. J Pathol 1997;183:131-133.

29 Störkel S, Eble JN, Adlakha K, et al. Classification of renal carcinoma. Cancer 1997;80:987-989.

30 Eble JN, Sauter G, Epstein JI, et al., (eds) World Health Organization Classification of Tumors. Pathology and Genetics of Tumours of the Urinary System and Male Genital Organs. IARC Press: Lyon, 2004.

31 Green LK, Grignon DJ, Ayala AG, et al. Role of nuclear grading in stage 1 renal cell carcinoma. Urology 1989;34:310-315.

32 Gelb AB, Shibuya RB, Weiss LM, et al. Stage I renal cell carcinoma. A clinicopathologic study of 82 cases. Am J Surg Pathol 1993;17:275-286.

33 Medeiros LJ, Gelb AB, Weiss LM. Renal cell carcinoma. Prognostic significance of morphologic parameters in 121 cases. Cancer 1988;61:1639-1651.

34 Bretheau D, Lechvallier E, de Fromont $\mathrm{M}$, et al. Prognostic value of nuclear grade of renal cell carcinoma. Cancer 1995;76:2543-2549.

35 Gudbjartsson T, Hardarson S, Petursdottir V, et al. Histological subtyping and nuclear grading of renal cell carcinoma and their implications for survival: a retrospective nation-wide study of 629 patients. Eur Urol 2005;48:593-600.

36 Petard J, Leroy E, Rioux-Leclercq N, et al. Prognostic value of histologic subtypes in renal cell carcinoma: a multicenter experience. J Clin Oncol 2005;23: 2763-2771.
37 Ficarra V, Martignoni G, Maffei N, et al. Original and reviewed nuclear grading according to the Fuhrman system: a multivariate analysis of 388 patients with conventional renal cell carcinoma. Cancer 2005; 103:68-75.

$38 \mathrm{Kim} \mathrm{H}$, Cho NH, Kim D, et al. Renal cell carcinoma in South Korea: a multicenter study. Hum Pathol 2004;35:1556-1563.

39 Amin MB, Amin MB, Tamboli $\mathrm{P}$, et al. Prognostic impact of histologic subtyping of adult renal neoplasms. An experience of 405 cases. Am J Surg Pathol 2002;26:281-291.

40 Ficarra V, Righetti R, Martignoni G, et al. Prognostic value of renal cell carcinoma nuclear grading: multivariate analysis of 333 cases. Urol Int 2001;67:130-134.

41 Delahunt B, Eble JN, McCredie MRE, et al. Morphologic typing of papillary renal cell carcinoma: comparison of growth kinetics and patient survival in 66 cases. Hum Pathol 2001;32:590-595.

42 Cheville JC, Blute ML, Zincke H, et al. Stage pT1 conventional (clear cell) renal cell carcinoma: pathological features associated with cancer specific survival. J Urol 2001;166:453-456.

43 Nazeer T, Amin MB, Delahunt B, et al. Interobserver variability of nuclear grading (NG) in renal cell carcinoma. Mod Pathol 1998;11:91A.

44 Al-Aynati M, Chen V, Salama S, et al. Interobserver and intraobserver variability using Fuhrman grading system for renal cell carcinoma. Arch Pathol Lab Med 2003;127:593-596.

45 Lang $\mathrm{H}$, Linder V, de Fromont M, et al. Multicentric determination of optimal interobserver agreement using Fuhrman grading system for renal cell carcinoma: assessment of 241 patients with $>15$-year followup. Cancer 2005;103:625-629.

46 Lanigan D, Conroy R, Barry-Walsh C, et al. A comparative analysis of grading systems in renal adenocarcinoma. Histopathology 1994;24:473-476.

47 Sika-Paotonu D, Bethwaite PB, McCredie MRE, et al. Nucleolar grade but not Fuhrman grade is applicable to papillary renal cell carcinoma. Am J Surg Pathol 2006;30:1091-1096.

48 Delahunt B, Sika-Paotonu D, Bethwaite PB, et al. Fuhrman grading is not appropriate for chromophobe renal cell carcinoma. Am J Surg Pathol 2007;31: 957-960.

49 Delahunt B. Sarcomatoid renal carcinoma: the final common dedifferentiation pathway of renal epithelial malignancies. Pathology 1999;31:185-190.

50 Cangiano T, Liao J, Naitoh J, et al. Sarcomatoid renal cell carcinoma: biologic behavior, prognosis and response to combined surgical resection and immunotherapy. J Clin Oncol 1999;17:523-528.

51 de Peralta-Venturina M, Moch H, Amin M, et al. Sarcomatoid differentiation in renal cell carcinoma. A study of 101 cases. Am J Surg Pathol 2001;25:275-278.

52 Cheville JC, Lohse CM, Zincke H, et al. Sarcomatoid renal cell carcinoma. An examination of underlying histologic subtype and an analysis of associations with patient outcome. Am J Surg Pathol 2004;28:435-441.

53 Mian BM, Bhadkamkar N, Slaton JW, et al. Prognostic factors and survival of patients with sarcomatoid renal cell carcinoma. J Urol 2002;167:65-70.

54 Jiang F, Moch H, Richter J, et al. Comparative genomic hybridization reveals frequent chromosome $13 q$ and $4 \mathrm{q}$ losses in renal cell carcinoma with sarcomatoid transformation. J Pathol 1998;185:382-388. 
55 Dijkhuizen T, Van Den Berg E, Van Den Berg A, et al. Genetics as a diagnostic tool in sarcomatoid renal-cell carcinoma. Int J Cancer 1997;72:265-269.

56 Brunelli M, Gobbo S, Cossu-Rocca P, et al. Chromosomal gains in the sarcomatoid transformation of chromophobe renal cell carcinoma. Mod Pathol 2007;20:303-309.

57 Delahunt B, Bethwaite PB, McCredie MRE, et al. The evolution of collagen expression in sarcomatoid renal cell carcinoma. Hum Pathol 2007;38:1372-1377.

58 Gökden N, Nappi O, Swanson PE, et al. Renal cell carcinoma with rhabdoid features. Am J Surg Pathol 2000;24:1329-1338.

59 Leroy X, Zini L, Buob D, et al. Renal cell carcinoma with rhabdoid features. Arch Pathol Lab Med 2007; 131:102-106.

60 Kuroiwa K, Kinoshita Y, Shiratsuchi H, et al. Renal cell carcinoma with rhabdoid features: an aggressive neoplasm. Histopathology 2002;41:538-548.

61 Delahunt B, Bethwaite PB, Nacey JN. Renal cell carcinoma in New Zealand. A national survival study. Urology 1994;43:300-309.

62 Flocks RH, Kadesky MC. Malignant neoplasms of the kidney: an analysis of 353 patients followed five years or more. J Urol 1958;79:196-201.

63 Petkovic SD. An anatomical classification of renal tumors in the adult. A basis for prognosis. J Urol 1959; 81:618-623.

64 Robson CJ. Radical nephrectomy for renal cell carcinoma. J Urol 1963;89:37-42.

65 Robson CJ, Churchill BM, Anderson W. The results of radical nephrectomy for renal cell carcinoma. J Urol 1969;101:297-301.

66 Harmen MH. TNM Classification of Malignant Tumours. Union Internationale Contre le Cancer: Geneva, 1978.

67 Jonas D, Thoma B, Beckett $\mathrm{H}$, et al. The value of morphological prognostic criteria in the assessment of renal cell carcinoma. Urol Int 1985;40:148-154.

68 Bassil B, Dosoretz DE, Prout GR. Validation of the tumor, nodes and metastases classification of renal cell carcinoma. J Urol 1985;134:450-454.

69 Siminovitch JMP, Montie JE, Straffon RA. Prognostic indicators in renal adenocarcinoma. J Urol 1983;130: 20-23.

70 Nurmi MJ. Prognostic factors in renal carcinoma. An evaluation of operative findings. Br J Urol 1984;56: 270-275.

71 Hermanek P, Sobin LH. TNM Classification of Malignant Tumours 4th edn Springer: Berlin, Heidelberg, New York, 1987.

72 Hermanek P, Henson DE, Hutter RVP, et al. TNM Supplement. A Commentary on Uniform Use. Springer: Berlin, Heidelberg, New York, Tokyo, 1993.

73 Sobin LH, Wittekind CL. TNM Classification of Malignant Tumours 5th edn Wiley-Liss: New York, 1997.

74 Green FL, Page DL, Fleming ID, et al. AJCC Cancer Staging Manual 6th edn. Springer: New York, 2002.

75 Moch H, Grasser T, Amin MB, et al. Prognostic utility of the recently recommended histologic classification and revised TNM staging system of renal cell carcinoma. A Swiss experience with 588 tumors. Cancer 2000;89:604-614.

76 Hafez KS, Fergany AF, Novick AC. Nephron sparing surgery for localized renal cell carcinoma: impact of tumor size or patient survival, tumor recurrence and TNM staging. J Urol 1999;162:1930-1933.

77 Kinouchi T, Saiki S, Meguro N, et al. Impact of tumor size on the clinical outcomes of patients with Robson Stage I renal cell carcinoma. Cancer 1999;85:689-695.

78 Gettman MT, Blute ML, Spotts B, et al. Pathologic staging of renal cell carcinoma: significance of tumor classification with the 1997 TNM staging system. Cancer 2001;91:354-361.

79 Zisman A, Pantuck AJ, Chao D, et al. Reevaluation of the 1997 TNM classification for renal cell carcinoma: T1 and T2 cutoff point at 4.5 rather than $7 \mathrm{~cm}$ better correlates with clinical outcome. J Urol 2001;166: 54-58.

80 Guinan P, Saffrin R, Stuhldreher D, et al. Renal cell carcinoma: comparison of the TNM and Robson stage groupings. J Surg Oncol 1995;59:186-189.

81 Delahunt B, Kittelson JM, McCredie MRE, et al. Prognostic importance of tumor size for localized conventional (clear cell) renal cell carcinoma. Assessment of TNM T1 and T2 tumor categories and comparison with other prognostic parameters. Cancer 2002;94:658-664.

82 Gofrit ON, Shapiro A, Pisov G, et al. Does stage T3a renal cell carcinoma embrace a homogenous group of patients? J Urol 2007;177:1682-1686.

83 Siddiqui SA, Igor F, Leibovitch BC, et al. Impact of tumor size on the predictive ability of the pT3a primary tumor classification for renal cell carcinoma. J Urol 2007;177:59-62.

84 Bonsib SM. T2 clear cell renal cell carcinoma is a rare entity: a study of 120 clear cell renal cell carcinoma. J Urol 2005;174:1199-1202.

85 Bonsib SM. Renal lymphatic and lymphatic involvement in sinus vein invasive (pT3b) clear cell renal cell carcinoma. A study of 40 cases. Mod Pathol 2006; 19:746-753.

86 Bonsib SM. Renal vein and venous extension in clear cell renal cell carcinoma. Mod Pathol 2007;20:44-53.

87 Thompson RH, Leibovich BC, Cheville JC, et al. Is renal sinus fat invasion the same as perinephric fat invasion for pT3a renal cell carcinoma? J Urol 2005;174:1218-1221.

88 Margulis V, Tamboli P, Martin SF, et al. Location of extrarenal tumor expression does not impact survival of patients with pT3a renal cell carcinoma. J Urol 2007;178:1878-1882.

89 Han KR, Bui MH, Pantuck AJ, et al. TNM T3a renal cell carcinoma: adrenal gland involvement is not the same as renal fat invasion. J Urol 2003;169:899-903.

90 Antonelli A, Cozzoli A, Simeone C, et al. Surgical treatment of adrenal metastasis from renal cell carcinoma: a single centre experience of 45 patients. BJU Int 2006;97:505-508.

91 Thompson RH, Cheville JC, Lohse CM, et al. Reclassification of patients with pT3 and pT4 renal cell carcinoma improves prognostic accuracy. Cancer 2005;104:53-60.

92 Ficcara V, Novara G, Iafrate $\mathrm{M}$, et al. Proposal for reclassification of the TNM staging system in patients with locally advanced (pT3-4) renal cell carcinoma according to the cancer-related outcome. Eur Urol 2007;51:722-729.

93 Siemer S, Lehmann J, Kamradt T, et al. Adrenal metastases in 1,635 patients with renal cell carcinoma: outcome and indication for adrenalectomy. J Urol 2004;171:2155-2159. 
94 Madbouly K, Al-Qahtani SM, Ghazwani Y, et al. Microvascular tumor invasion: prognostic significance in low stage renal cell carcinoma. Urology 2007;69:670-674.

95 Van Poppel $\mathrm{H}$, Vandenriessche $\mathrm{H}$, Boel $\mathrm{K}$, et al. Microvascular invasion is the most relevant prognosticator after radical nephrectomy for clinically nonmetastatic renal cell carcinoma. J Urol 1997; 158:45-49.

96 Goncalves PD, Srougi M, Dall'lio MF, et al. Low clinical stage renal cell carcinoma: relevance of microvascular tumor invasion as a prognostic parameter. J Urol 2004;172:470-474.

97 Lang $\mathrm{H}$, Lindner V, Letourneux $\mathrm{H}$, et al. Prognostic value of microscopic venous invasion in renal cell carcinoma: long-term follow-up. Eur Urol 2004;46: 331-335.

98 Blute ML, Leibovich BC, Lohse CM, et al. The Mayo Clinic experience with surgical management complications and outcome for patients with renal cell carcinoma and venous tumour thrombus. BJU Int 2004;94:33-41.

99 Klaver S, Joniau S, Suy R, et al. Analysis of renal cell carcinoma with subdiaphragmatic macroscopic venous invasion (T3b). BJU Int 2007;101:444-449.

100 Heferkamp A, Bastian PJ, Jakobi H, et al. Renal cell carcinoma with tumor thrombus extension into the vena cava: prospective long-term followup. J Urol 2007;177:1703-1708.

101 Klatte T, Pantuck AJ, Riggs SB, et al. Prognostic factors for renal cell carcinoma with tumor thrombus extension. J Urol 2007;178:1189-1195.

102 Lambert EH, Pierorazio PM, Shabsigh A, et al. Prognostic risk stratification and clinical outcomes in patients undergoing surgical treatment for renal cell carcinoma with vascular tumor thrombus. Urology 2007;69:1054-1058.

103 Moinzadeh A, Libertino JA. Prognostic significance of tumor thrombus levels in patients with renal cell carcinoma and venous tumor thrombus extension. Is all T3b the same? J Urol 2004;171:598-601.

104 Leibovich BC, Cheville JC, Lohse CM, et al. Cancer specific survival for patients with pT3 renal cell carcinoma-can the 2002 primary tumor classification be improved? J Urol 2005;173:716-719.

105 Terakawa T, Miyake H, Takenaka A, et al. Clinical outcome of surgical management for patients with renal cell carcinoma involving the inferior vena cava. Int J Urol 2007;14:781-784.
106 Ficarra V, Galfano A, Guille F, et al. A new staging system for locally advanced (pT3-4) renal cell carcinoma: a multicenter European study including 2,000 patients. J Urol 2007;178:418-424.

107 Giuliani L, Giberti C, Martorana G, et al. Radical extensive surgery for renal cell carcinoma: long-term results and prognostic factors. J Urol 1990;143: 468-474.

108 Masuda H, Kurita Y, Suzuki A, et al. Prognostic factors for renal cell carcinoma: a multivariate analysis of 320 cases. Int J Urol 1997;4:247-253.

109 Schafhauser W, Ebert A, Brod J, et al. Lymph node involvement in renal cell carcinoma and survival chance by systematic lymphadenectomy. Anticancer Res 1999;19:1573-1578.

110 Joslyn SA, Sirintrapun SJ, Konety BR. Impact of lymphadenectomy and nodal burden in renal cell carcinoma: retrospective analysis of the national surveillance, epidemiology and end results database. Urology 2005;65:675-680.

111 Terrone C, Guercio S, DeLuca S, et al. The number of lymph nodes examined and staging accuracy in renal cell carcinoma. BJU Int 2003;91:37-40.

112 Terrone C, Cracco C, Porpiglia F, et al. Reassessing the current TNM lymph node staging for renal cell carcinoma. Eur Urol 2006;49:324-331.

113 Margulis V, Tamboli P, Matin SF, et al. Analysis of clinicopathologic predictors of oncologic outcome provides insight into the natural history of surgically managed papillary renal cell carcinoma. Cancer 2008;112:1480-1488.

114 Minervini A, Lilas L, Morelli G, et al. Regional lymph node dissection in the treatment of renal cell carcinoma: is it useful in patients with no suspected adenopathy before or during surgery? BJU Int 2001;88:169-172.

115 Pantuck AJ, Zisman A, Dorey F, et al. Renal cell carcinoma with retroperitoneal lymph nodes: role of lymph node dissection. J Urol 2003;169:2076-2083.

116 Johnsen JA, Hellsten S. Lymphatogenous spread of renal cell carcinoma: an autopsy study. J Urol 1997; 157:450-453.

117 Horiguchi A, Ito K, Sumitomo M, et al. Intratumoral lymphatics and lymphatic invasion are associated with tumor aggressiveness and poor prognosis in renal cell carcinoma. Urology 2008;71:928-932.

118 Ishikawa Y, Aida S, Tamai S, et al. Significance of lymphatic invasion and proliferation on regional lymph node metastasis in renal cell carcinoma. Am J Clin Pathol 2007;128:198-207. 